\section{Godt tilskudd til pasientlitteraturen om brystkreft}

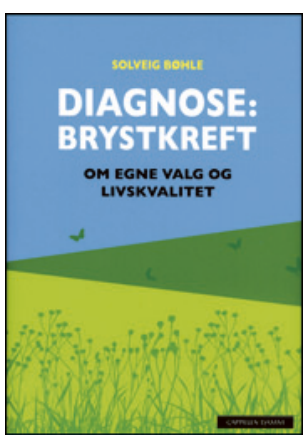

\author{
Solveig Bøhle
}

\section{Diagnose: Brystkreft}

Om egne valg og livskvalitet. $105 \mathrm{~s}$.

Oslo: Cappelen Damm, 2013. Pris NOK 329

ISBN 978-82-02-42248-6

Undertittelen - Om egne valg og livskvalitet - vekker interessen hos meg som møter kvinner med brystkreft daglig i arbeidet mitt. Forfatteren har jobbet mye med helsejournalistikk, hun stiller mange spørsmål og gir noen svar. Boken er tiltalende, velskrevet og lettlest.

Hun tar oss med inn i prosessen hun gikk gjennom da hun fikk diagnostisert brystkreft. Det er en personlig beretning om møtet med helsevesenet og bakgrunnen for egne valg. Hun refererer også til andre kvinners erfaring med samme diagnose og gir med dette et nyansert bilde. Mange av spørsmålene kjenner jeg igjen fra mine egne møter med pasienter med brystkreft. Hva kan jeg gjøre selv? Hva skal jeg spise? Skal jeg trene? Skal jeg ta imot den anbefalte behandlingen? Hun legger vekt på at det er viktig å ta sine egne valg, og at det er viktig å snakke både med behandlende lege og andre man har tillit til.

Hun intervjuer både klinikere og forskere innen tradisjonell medisin og viser at det forskes mye på brystkreft, men det er viktig å ha klart for seg at dette ikke er noen lærebok i utredning og behandling av brystkreft. En svakhet er at det ikke går klart frem hva som har klinisk nytteverdi i dag.

Forfatteren er opptatt av alternative behandlings- og terapiformer. Mange i denne pasientgruppen benytter ulike alternative behandlinger, enten som supplement til, eller som alternativ til, tradisjonell behandling. Boken gir et innblikk i landskapet pasientene beveger seg i.

Jeg synes teksten gir et godt innblikk i spørsmålene og valgene kvinner blir stilt overfor i møtet med diagnosen brystkreft, og hvor viktig møtet med helsevesenet er. Jeg tror både behandlere og pasienter kan ha glede og nytte av å lese denne boken.

Ingvild Ona Moberg

Overlege, Avdeling for bryst- og endokrinkirurgi

Oslo universitetssykehus, Ullevål

\section{Nyttig og grundig veileder $\mathrm{i}$ barneradiografi}

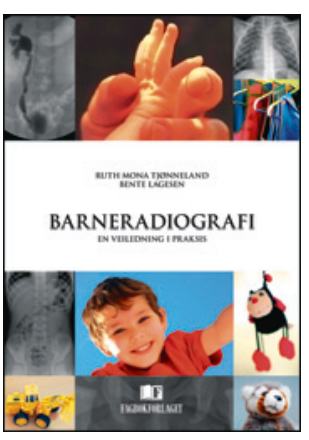

Ruth Mona Tjønneland, Bente Lagesen Barneradiografi

En veiledning i praksis. 229 s, tab, ill. Bergen: Fagbokforlaget, 2013. Pris 279 ISBN 978-82-450-1182-1

Målgruppen er primært radiografer, både under utdanning og $i$ arbeid ved norske sykehus. Treningsgrunnlaget som skal til for å få utført en god røntgenundersøkelse av barn, blir ofte spinkelt utenom spesialavdelinger, og denne boken er et konkret bidrag til å høyne kvaliteten på nødvendige utredninger av barn. Forfatterne har arbeidet med barneradiografi i mange år, og de deler sine erfaringer med barn «på røntgen», med intensjon om at røntgenundersøkelsen skal bli vellykket både for barnet, foresatte og personalet.

Boken er bygd opp med oversiktlige kapitler som omhandler barns rettigheter, hva som skiller barn fra voksne pasienter, bruk av immobilisering, sedasjon og kontrastmidler. Strålehygieniske forhold er grundig diskutert i tråd med at temaet er helt sentralt i all virksomhet der barn utsettes for ioniserende stråling.

Forfatterne har lagt stor vekt på riktig håndtering av barn og pårørende $\mathrm{i}$ en situasjon som kan være krevende for både besøkende og røntgenpersonalet. Hele gjennomføringen av en radiologisk prosedyre gjennomgås, fra forberedelse av undersøkelsen på laboratoriet, til mottak av pasienten med følge og orientering om hvorfor og hvordan undersøkelsen foregår. Dette er en praktisk veileder, og tips for radiografen om posisjonering, holdeteknikk, eksponeringsparametere, innblending, stråleretning, valg av kontrastmiddel osv. får en fremtredende plass. De aller fleste radiologiske undersøkelsestyper som barn kan gjennomgå ved norske sykehus, omtales og illustreres med fotografier, røntgenbilder og strektegninger som er tydelige og velvalgte. Spesielle kapitler omhandler computertomografi (CT) og magnetisk resonansundersøkelser (MR) av barn.

Dette er den første samlede beskrivelsen av barneradiografi på norsk, og det er etter min mening en bok som oppfyller forfatternes intensjon om å levere et praktisk og nyttig bidrag til at barn behandles på en god måte når nødvendige radiologiske undersøkelser må utføres.

Den bør finnes ved alle norske røntgenavdelinger og barneavdelinger og bør også inngå som et viktig grunnlag i utdanningen av norske radiografer. Videre kan boken være nyttig som et orienterende oppslagsverk for alle leger som henviser barn til røntgenundersøkelser, og en god kilde til informasjon for barnesykepleiere som skal forberede barn for røntgenundersøkelse, og eventuelt følge barn til røntgenavdelingen.

Bjarne Smevik

Enhetsoverlege, Bilde- og intervensjonsklinikk

Oslo universitetssykehus 